\title{
Selectivity of chlorantraniliprole and lambda-cyhalothrin to the egg parasitoid Telenomus podisi (Hymenoptera: Platygastridae)
}

\author{
Seletividade de chlorantraniliprole e lambda-cialotrina ao \\ parasitoide de ovos Telenomus podisi (Hymenoptera: Platygastridae)
}

\author{
Gabriela Vieira Silva ${ }^{1}$; Adeney de Freitas Bueno²; \\ Bruna Magda Favetti ${ }^{*}$; Pedro Manuel Oliveira Janeiro Neves ${ }^{4}$
}

\begin{abstract}
Soybean plants host a diverse complex of pest insects, which can occur simultaneously during crop development. Thus, the use of egg parasitoids for the management of Euschistus heros (Fabricius) (Hemiptera: Pentatomidae) depends on the selectivity of the pesticides to the stink bug. Thus, the selectivity of the active ingredients chlorantraniliprole and chlorantraniliprole + lambda-cyhalothrin to the parasitoid Telenomus podisi (Ashmead) (Hymenoptera: Platygastridae) was evaluated. The bioassays were carried out under controlled conditions $\left(27 \pm 2^{\circ} \mathrm{C}\right.$ and $50 \pm 10 \%$ relative humidity) for the pupal and adult phases of the parasitoid. The design was completely randomized, with 10 treatments and five replicates composed of the insecticides chlorantraniliprole and chlorantraniliprole + lambdacyhalothrin in different doses, as well as a negative control using water and a positive control using chlorpyrifos. We used a Potter Tower for the applications, and evaluations were carried out 24, 72, and 120 hours after the applications. Experimental methods and analyses to determine the harmfulness of the products to the insects were in accordance with International Organization for Biological Control standards. Chlorantraniliprole, at all doses tested, was less harmful to the parasitoid, especially in the adult phase; the doses were classified as class 1 . The chlorantraniliprole + lambda-cyhalothrin mixture at its highest dose was classified as class 4 , at 72 and 120 hours after application. For the pupal phase of the parasitoid, there were no significant differences, and the products were classified as class 1 , except for the highest dose of chlorantraniliprole, which classified as class 2, at 24 hours after application. Thus, chlorantraniliprole can be considered a tool in the management of soybean pests. Its selectivity to T. podisi under the conditions tested presents low or no negative interference when sprayed on pupae and adults. However, the chlorantraniliprole + lambda-cyhalothrin mixture should be used with caution, respecting the time of application and the recommended doses, as it interferes negatively in the development of the parasitoid and should be replaced when possible.
\end{abstract}

Key words: Biological control. Chemical control. Integrated pest management. Soybean.

\section{Resumo}

A soja apresenta um diversificado complexo de insetos-praga, que podem ocorrer no mesmo período de desenvolvimento da cultura. Assim, a utilização de parasitoides de ovos para o manejo de Euschistus heros (Fabricius) (Hemiptera: Pentatomidae) depende em parte da seletividade dos agrotóxicos

${ }^{1}$ Enga $^{\text {a }}{ }^{a} r^{\mathrm{a}}$, Bióloga, Dra ${ }^{\mathrm{a}}$, Centro Universitário Filadélfia, UNIFIL, Londrina, PR, Brasil. E-mail: gabriela1vieirasilva@gmail.com

${ }^{2}$ Eng $^{\mathrm{o}}$ Agr $^{\mathrm{O}}$, Dr., Pesquisador, Empresa Brasileira de Pesquisa Agropecuária, EMBRAPA Soja, Londrina, PR, Brasil. E-mail: adeney.bueno@embrapa.br

${ }^{3}$ Bióloga, Dr ${ }^{\mathrm{a}}$, Instituto Agronômico do Paraná, IAPAR, Londrina, PR, Brasil. E-mail: favettibruna@yahoo.com.br

${ }^{4}$ Eng $^{\mathrm{O}}$ Agro , Prof. Dr., Departamento de Agronomia, CCA, Universidade Estadual de Londrina, UEL, Londrina, PR, Brasil. E-mail: pedroneves@uel.br

* Author for correspondence

Received: Aug. 29, 2017 - Approved: Feb. 13, 2018 
utilizados para o controle de pragas que atacam a lavoura concomitantemente aos percevejos. A partir disso, avaliou-se a seletividade dos princípios ativos chlorantraniliprole e chlorantraniliprole + lambdacialotrina no desenvolvimento do parasitoide Telenomus podisi (Ashmead) (Hymenoptera: Platygastridae). Os bioensaios foram realizados em laboratório sob condições controladas (temperatura $27 \pm 2{ }^{\circ} \mathrm{C}$ e UR $50 \pm 10 \%$ ) nas fases de pupa e adulto do parasitoide. O delineamento utilizado foi inteiramente casualizado, com dez tratamentos e cinco repetições compostas pelos inseticidas chlorantraniliprole e chlorantraniliprole + lambdacialotrina em diferentes doses, bem como um controle negativo com água. As aplicações foram feitas com a Torre de Potter e as avaliações realizadas após 24, 72 e 120 horas. A condução do experimento e classificação utilizada para determinar a nocividade dos produtos aos insetos foi de acordo com as normas da IOBC (International Organization for Biological and Integrated Control). Chlorantraniliprole em todas as doses foi menos nocivo ao parasitoide, principalmente sobre a fase adulta, onde as doses se enquadraram na classe 1 (inócuo). A mistura chlorantraniliprole + lambdacialotrina em sua maior dose foi enquadrada na classe 4 (nocivo) às 72 e 120 horas após a aplicação. Para a fase de pupa do parasitoide, não houve diferenças significativas, sendo os produtos enquadrados na classe 1 (inócuo), exceto para a maior dose de clorantraniliprole, pertencente à classe 2 (levemente nocivo) 24 horas após a aplicação. Assim, chlorantraniliprole pode ser considerado uma ferramenta no manejo de pragas da soja considerando a sua seletividade a T. podisi nas condições testadas, pois não apresenta interferência negativa no desenvolvimento do parasitoide, quando pulverizado sobre pupas e adultos. Entretanto, a mistura chlorantraniliprole + lambda-cialotrina deve ser utilizada com cautela, respeitando-se o momento de aplicação e as doses recomendadas, pois interfere negativamente no desenvolvimento do parasitoide, devendo ser substituída quando possível.

Palavras-chave: Controle biológico. Controle químico. Manejo integrado de pragas. Soja.

\section{Introduction}

Integrated pest management (IPM) uses different control tactics in a concerted manner. The goal is to complement natural, biological forms of pest control and to maintain pest populations below the levels that cause damage, thus conserving the environment and beneficial arthropods. In this goal, parasitoids and agrochemicals can be used simultaneously, provided there is compatibility between these control methods (REISS et al., 1998; POLANCZYK et al., 2010). Thus, the selectivity of insecticides to natural enemies is of great importance and should be evaluated when choosing insecticides for IPM programs (BUENO et al., 2012).

Insecticide selectivity to natural enemies has been studied for decades (HASSAN et al., 1998; ZOTTI et al., 2008; FONSECA et al., 2012; DIAMANTINO et al., 2014). However, in addition to being specific to the biological organism under study and its phases of development, pesticide selectivity is directly related to its concentration (DESNEUX et al., 2004). Changes in dosage can directly impact its selectivity classification
(BUENO et al., 2017). Those changes can occur, for example, after occurence of Helicoverpa armigera (Hübner) (Lepidoptera: Noctuidae) in crops in Brazil (CZEPAK et al., 2013), when pesticides started to be used in higher concentrations than those normally recommended for other pest species, since target-pest populations already showed resistance to several insecticides (WYCKHUYS et al., 2013). Thus, such intensified use of insecticides can significantly impact beneficial entomofauna and lead to changes in IPM strategies (BUENO et al., 2008).

Helicoverpa armigera gained attention in soybeans, where it is detrimental throughout the vegetative and reproductive stages of plant development because it consumes leaves and pods (WANG; LI, 1984; CZEPAK et al., 2013). It occurs simultaneously with other important pests, such as the brown stink bug Euschistus heros (Fabricius) (Hemiptera: Pentatomidae). Considering the cultivation of soybeans as a system in which various organisms coexist, the chemical control of $H$. armigera can impact the natural biological control of other pests. Pesticides can have deleterious effects 
on the natural enemies of the brown stink bug when nonselective products or abusive pesticide dosages are used (POMARI-FERNANDES et al., 2015).

Among the natural enemies of E. heros, the egg parasitoid Telenomus podisi (Ashmead) (Hymenoptera: Platygastridae) stands out as a species that shows a preference for this stink bug's eggs (CORRÊA-FERREIRA; AZEVEDO, 2002, DOETZER; FOERSTER, 2007). This further reinforces the importance of integrating different control tactics into IPM and the study of the selectivity of new products and/or new dosages.

Among the products used in the management of $H$. armigera are chlorantraniliprole and a mixture of chlorantraniliprole with lambda-cyhalothrin. However, few studies have assessed the effect of chlorantraniliprole or lambda-cyhalothrin on $T$. podisi at higher doses that might be used to control
$H$. armigera. Therefore, we evaluated the possible impacts of spraying chlorantraniliprole and lambdacyhalothrin during the pupal and adult stages of $T$. podisi and determined the toxicity of different doses of those chemicals.

\section{Materials and Methods}

The insects used in the bioassays were taken from laboratory rearing that is maintained in the Embrapa Soybean. The eggs of E. heros that were used in the bioassays were previously stored in liquid nitrogen.

We used an application rate of $150 \mathrm{~L}^{-}$ 1. The solutions for each treatment (Table 1) were sprayed through a Potter Tower previously calibrated to deposit $1.25 \pm 0.25 \mathrm{mg}$ per $\mathrm{cm}^{2}$, accordingly standardized protocols recommended by the International Organization for Biological Control (IOBC) (HASSAN et al., 1985).

Table 1. Insecticides tested during the pupal and adult phases of the egg parasitoid Telenomus podisi.

\begin{tabular}{|c|c|c|c|c|}
\hline $\begin{array}{c}\text { Commercial product } \\
\text { (c.p.) }\end{array}$ & Formulation & Active ingredient (a.i.) & $\begin{array}{l}\text { Dose c.p. } \\
\left(\mathrm{mL} \mathrm{ha}^{-1}\right)\end{array}$ & $\begin{array}{c}\text { Dose a.i. } \\
\left(\mathrm{g} \text { a.i. } \text { ha }^{-1}\right)\end{array}$ \\
\hline Premio $^{\circledR}$ & $200 \mathrm{SC}$ & chlorantraniliprole $^{1}$ & 50 & 10 \\
\hline Premio $^{\circledR}$ & $200 \mathrm{SC}$ & chlorantraniliprole $^{1}$ & 75 & 15 \\
\hline Premio $^{\circledR}$ & $200 \mathrm{SC}$ & chlorantraniliprole $^{1}$ & 100 & 20 \\
\hline Premio $^{\circledR}$ & $200 \mathrm{SC}$ & chlorantraniliprole $^{1}$ & 150 & 30 \\
\hline Premio $^{\circledR}$ & $200 \mathrm{SC}$ & chlorantraniliprole $^{1}$ & 250 & 50 \\
\hline Ampligo $^{\circledR}$ & $100 / 50 \mathrm{SC}$ & $\begin{array}{l}\text { chlorantraniliprole+ } \\
\text { lambda-cyhalothrin }{ }^{2}\end{array}$ & 100 & $10+5$ \\
\hline Ampligo $^{\circledR}$ & $100 / 50 \mathrm{SC}$ & $\begin{array}{l}\text { chlorantraniliprole+ } \\
\text { lambda-cyhalothrin }\end{array}$ & 300 & $30+15$ \\
\hline Ampligo $^{\circledR}$ & $100 / 50 \mathrm{SC}$ & $\begin{array}{l}\text { chlorantraniliprole+ } \\
\text { lambda-cyhalothrin }\end{array}$ & 500 & $50+25$ \\
\hline $\begin{array}{c}\text { Water } \\
\text { (negative control) }\end{array}$ & - & - & - & - \\
\hline $\begin{array}{l}\text { Lorsban } 480 \mathrm{BR}^{\circledR} \\
\text { (positive control) }\end{array}$ & $480 \mathrm{EC}$ & chlorpyrifos & 2000 & 960 \\
\hline
\end{tabular}

${ }^{1}$ Insecticide from the anthranilamides chemical group. ${ }^{2}$ Insecticide from the pyrethroids chemical group. 
Selectivity of chlorantraniliprole and chlorantraniliprole + lambda-cyhalothrin to pupae of T. podisi

Cards containing $T$. podisi pupae inside $E$. heros eggs (13 days post-parasitism) were sprayed (parasitoids pupae approximately 24 hours before adult emergence). Subsequently, the cards remained in environmental conditions $\left(27 \pm 2{ }^{\circ} \mathrm{C}\right.$ and $50 \pm$ $10 \% \mathrm{RH}$ ) for 2 hours in order for the insecticide to dry. Thereafter, the cards were transferred to standard IOBC cages (DEGRANDE et al., 2002).

Contact cages proposed by Degrande et al. (2002), with glass panels composing the bottom and the top of the cage, were used. The outer surface of the glass plates was covered with black cardboard paper that had a center square $(7 \mathrm{~cm} \times 7$ $\mathrm{cm}$ ) removed. The cards containing $T$. podisi pupae were inserted into the cages. Twenty-four, 72, and $120 \mathrm{~h}$ after the emergence of the parasitoids, new cards were inserted with approximately 70 E. heros eggs. The following parameter were evaluated: emergence of adults (\%), parasitism (\%) of $\mathrm{F}_{0}$ generation, and emergence $(\%)$ of $\mathrm{F}_{1}$ generation.

Parasitism capacity of $T$. podisi adults from pupae sprayed with chlorantraniliprole and chlorantraniliprole + lambda-cyhalothrin

We used four females, which emerged from sprayed eggs (Table 1), per replication for the bioassays. Approximately $40 \mathrm{E}$. heros eggs were attached to $2.5 \mathrm{~cm} \times 5 \mathrm{~cm}$ white paperboard cards. The cards were placed into Duran-type tubes containing droplets of pure honey for parasitoid feeding. They were then given to T. podisi females for parasitism. The tubes were sealed with plastic film and kept in temperature-controlled chambers regulated at $25 \pm$ $2{ }^{\circ} \mathrm{C}$ and $70 \pm 10 \% \mathrm{RH}$, with a photoperiod of $14 / 10$ hours light/dark. Every 24 hours, the cards were removed and changed. This procedure was repeated daily for a period of 15 days. The cards removed from the tubes were placed into plastic bags and kept in the same environmental conditions as where they were parasitized. We assessed the total number of parasitized eggs per female, lifetime parasitism $(\%)$, adult emergence $(\%)$, the longevity of parental females (days), and the sex ratio of the parasitoids.

Selectivity of chlorantraniliprole and chlorantraniliprole + lambda-cyhalothrin to $T$. podisi adults

Glass plates $(13 \times 13 \mathrm{~cm}, 2 \mathrm{~mm}$ thick $)$ were sprayed with various doses of the products (Table 1). Afterwards, they remained in environmental conditions $\left(27 \pm 2{ }^{\circ} \mathrm{C}\right.$ and $\left.50 \pm 10 \% \mathrm{RH}\right)$ for 2 hours, for complete evaporation of the pesticides, leaving a film of the product on the glass to allow for contact between the parasitoids and the insecticides. In the preparation of cages, the glass plates were covered externally with black cardboard paper, whose central square $(7 \mathrm{~cm} \times 7 \mathrm{~cm})$ was removed (DEGRANDE et al., 2002).

Telenomus podisi adults at 48 hours of age were inserted into the contact cage through emergence tubes (CARMO et al., 2009), connected through holes in the cages. The parasitoids were given cards containing 100 non-sprayed E. heros eggs after 24, 72 , and 120 hours, to assess the parasitism of the $\mathrm{F}_{0}$ generation, emergence of adults, and sex ratio of the $\mathrm{F}_{1}$ generation. Cardstock cards containing honey droplets were placed inside each cage to feed the parasitoids.

\section{Statistical analyses}

The experiments were carried out using a completely randomized experimental design, with 10 treatments and five repetitions for each bioassay. The results were submitted to exploratory analyses to evaluate the normality assumptions of the residuals (SHAPIRO and WILK, 1965), the homogeneity of variance of the treatments, and the additivity of the model (BURR and FOSTER, 1972), to apply analysis of variance (ANOVA). The means were compared by the $\mathrm{F}$ test or the Tukey 
test ( $p \leq 0.05)$ (SAS Institute, 2009). In addition, the effect of the treatments on T. podisi was determined by comparison with the negative control (water), calculated with the formula used by Hassan et al. (1985):

- Adults: $\mathrm{E}_{1}(\%)=(1-$ Parasitism in the treatment $/$ Parasitism in the negative control) $\times 100$;

- Pupae: $\mathrm{E}_{2}(\%)=(1-$ Viability of sprayed pupae with the treatment/viability of the pupae in the negative control) $\times 100$.

Thus, the treatments were classified according to their toxicity: class $1=$ innocuous $(\mathrm{E}<30 \%)$, class $2=$ slightly harmful $(30 \% \leq \mathrm{E}<80)$, class 3 $=$ moderately harmful $(80 \% \leq \mathrm{E}<99)$, and class $4=$ noxious ( $\mathrm{E} \geq 99 \%$ ) (HASSAN et al., 1985).

\section{Results}

Selectivity of chlorantraniliprole and chlorantraniliprole + lambda-cyhalothrin to $T$. podisi pupae

The largest percentage of $T$. podisi emergence (79.84\%) occurred in the control treatment with water, followed by the lower concentrations of 10 and $15 \mathrm{~g}$ active ingredient (a.i.) $\mathrm{ha}^{-1}$ of chlorantraniliprole, with percentages of $71.34 \%$ and $73.53 \%$, respectively. This was followed by the lowest concentration of $10+5 \mathrm{~g}$ a.i. ha $\mathrm{h}^{-1}$ (chlorantraniliprole + lambda-cyhalothrin), with a percentage of $70.86 \%$ (Table 2). The emergence percentages were $66.00 \%, 67.02 \%$, and $63.28 \%$ at the highest concentrations of 20,30 , and $50 \mathrm{~g}$ a.i. ha $^{-1}$ of chlorantraniliprole, respectively. The mixture of $20+10 \mathrm{~g}$ a.i. ha $\mathrm{ha}^{-1}$ (chlorantraniliprole + lambda-cyhalothrin) had a percentage of $64.73 \%$. The mixture with higher concentrations of chlorantraniliprole + lambda-cyhalothrin $(30+$ $15 \mathrm{~g}$ a.i. $\mathrm{ha}^{-1}$ ) resulted in $54.05 \%$ emergence. The lowest percentage of emergence was observed in the chlorpyrifos treatment (51.09\%) (Table 2).

Table 2. Emergence of Telenomus podisi from pupae sprayed with chlorantraniliprole and chlorantraniliprole + lambda-cyhalothrin in different doses.

\begin{tabular}{cc}
\hline $\begin{array}{c}\text { Treatment } \\
\left(\mathbf{g} \text { a.i. } \mathbf{~ h a}^{-1}\right)\end{array}$ & Emergence (\%) $^{\mathbf{1 , 2}}$ \\
\hline Chlorantraniliprole 10 & $71.34 \pm 3.07 \mathrm{ab}$ \\
Chlorantraniliprole 15 & $73.53 \pm 3.96 \mathrm{ab}$ \\
Chlorantraniliprole 20 & $66.00 \pm 3.33 \mathrm{abc}$ \\
Chlorantraniliprole 30 & $67.02 \pm 1.71 \mathrm{abc}$ \\
Chlorantraniliprole 50 & $63.28 \pm 3.32 \mathrm{abc}$ \\
Chlorantraniliprole 10 + lambda-cyhalothrin 5 & $70.86 \pm 2.93 \mathrm{ab}$ \\
Chlorantraniliprole 20 + lambda-cyhalothrin 10 & $64.73 \pm 1.90 \mathrm{abc}$ \\
Chlorantraniliprole 30 + lambda-cyhalothrin 15 & $54.05 \pm 1.09 \mathrm{dc}$ \\
Water & $79.84 \pm 4.30 \mathrm{a}$ \\
Chlorpyrifos 960 & $51.09 \pm 3.32 \mathrm{~d}$ \\
\hline CV (\%) & 10.32 \\
$\mathrm{~F}$ & 8.04 \\
$p$ & $<0.0001$ \\
\hline
\end{tabular}

${ }^{1}$ Means $( \pm \mathrm{SE})$ followed by the same letter in the column do not differ by the Tukey test $(p \leq 0.05) .{ }^{2}$ Emergence $(\%)$ of $T$. podisi that were sprayed in the pupal phase with chlorantraniliprole and chlorantraniliprole + lambda-cyhalothrin in various concentrations. ${ }^{\mathrm{n}} \mathrm{ANOVA}$ not significant. 
For the percentage of parasitism of adults that emerged from sprayed pupae, for all periods tested, the chlorpyrifos spray resulted in the lowest values. These values were $28.24 \%, 29.12 \%$, and $16.85 \%$, respectively, at 24,72 , and 120 hours. The percentage of parasitism 24 hours after emergence was higher for the water treatment $(77.48 \%)$ and for $20 \mathrm{~g}$ a.i. ha $\mathrm{h}^{-1}$ of chlorantraniliprole $(73.48 \%)$. Chlorantraniliprole at $50 \mathrm{~g}$ a.i. $\mathrm{ha}^{-1}$ resulted in a lower percentage of parasitism at 53.12\% (Table 3).

At 72 hours after emergence, the highest percentage of parasitism was observed in the treatment with $15 \mathrm{~g}$ a.i. $\mathrm{ha}^{-1}$ of chlorantraniliprole (77.4\%). For chlorantraniliprole at $50 \mathrm{~g}$ a.i. ha1 , a lower percentage of parasitism was observed: $52.93 \%$. The other treatments ranged from $58.28 \%$ for the mixture of chlorantraniliprole + lambdacyhalothrin at $30+15 \mathrm{~g}$ a.i. ha ${ }^{-1}$, to $69.4 \%$ for $10+$ $5 \mathrm{~g}$ a.i. ha ${ }^{-1}$. For parasitism at 120 hours, the values were more than $70 \%$, with no difference among the treatments, except for chlorpyrifos (Table 3).

Regarding the classification of parasitoid toxicity, the results indicate that the concentrations were

within class 1 (innocuous) according to the IOBC classification, except for $50 \mathrm{~g}$ a.i. $\mathrm{ha}^{-1}$ of chlorantraniliprole, which was classified as slightly harmful (class 2) (Table 4).

Parasitism capacity of $T$. podisi adults from pupae sprayed with chlorantraniliprole and chlorantraniliprole + lambda-cyhalothrin

The total number of parasitized eggs was significantly lower only in the chlorpyrifos treatment, where each non-sprayed female parasitized 0.5 E. heros eggs (Table 5). Females sprayed with chlorantraniliprole, chlorantraniliprole + lambda-cyhalothrin, and water parasitized between 79.20 eggs in the treatment with $20 \mathrm{~g}$ a.i. ha ${ }^{-1}$ chlorantraniliprole to 106.6 eggs in the treatment with water (Table 5).

Significant differences occurred in the emergence of $T$. podisi only for the treatment with chlorpyrifos, with a percentage of $8.33 \%$. The remaining treatments varied between $47.93 \%$ and $58.20 \%$ viability for chlorantraniliprole at $15 \mathrm{~g}$ a.i. $\mathrm{ha}^{-1}$ and chlorantraniliprole + lambda-cyhalothrin at $30+15 \mathrm{~g}$ a.i. $\mathrm{ha}^{-1}$, respectively, without significant differences (Table 5).

The sex ratio was shown to vary according to the product/concentration tested. There was emergence of $100 \%$ males in the treatment with chlorpyrifos and $86 \%$ in the mixture of chlorantraniliprole + lambda-cyhalothrin at $20+10 \mathrm{~g}$ a.i. ha ${ }^{-1}$. For the other treatments, the sex ratio did not differ and had values between 0.36 for the mixture of chlorantraniliprole + lambda-cyhalothrin at $30+15$ g a.i. ha ${ }^{-1}$ to 0.66 for chlorantraniliprole at $50 \mathrm{~g}$ a.i. ha $^{-1}$ (Table 5).

The longevity of the parent females was lower for chlorpyrifos (1 day) and higher for water (19.55 days). Among the tested concentrations of chlorantraniliprole and chlorantraniliprole + lambdacyhalothrin at $10+5$ and $20+10 \mathrm{~g}$ a.i. ha ${ }^{-1}$, there was no difference, with variations between 14.85 and 17.85 days for the treatments of chlorantraniliprole at $30 \mathrm{~g}$ a.i. $\mathrm{ha}^{-1}$ and chlorantraniliprole + lambdacyhalothrin at $10+5 \mathrm{~g}$ a.i. $\mathrm{ha}^{-1}$, respectively. Females treated with the higher concentration mixture (30 $+10 \mathrm{~g}$ a.i. ha ${ }^{-1}$ ) had a longevity of approximately 14.20 days (Table 5). 


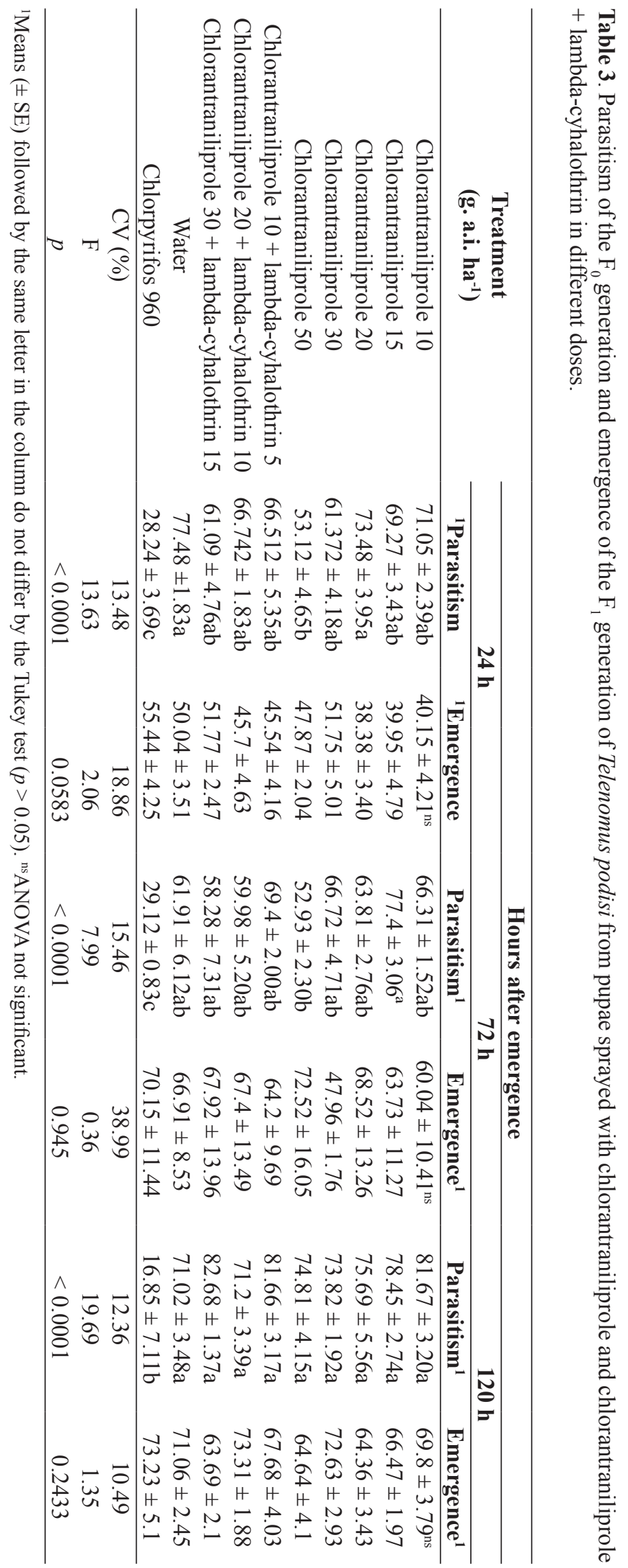


Table 4. Effect of different insecticides and doses on pupae of Telenomus podisi and their classification according to the norms of the International Organization for Biological Control (IOBC).

\begin{tabular}{ccccccc}
\hline $\begin{array}{c}\text { Treatment } \\
\text { (g. a.i. ha' }\end{array}$ & \multicolumn{2}{c}{$\mathbf{2 4} \mathbf{~ h}$} & \multicolumn{2}{c}{$\mathbf{7 2} \mathbf{~ h}$} & \multicolumn{2}{c}{$\mathbf{1 2 0 ~ h}$} \\
& $\mathbf{E \%}^{\mathbf{1}}$ & $\mathbf{C l a s s}^{\mathbf{2}}$ & $\mathbf{E \%}^{\mathbf{1}}$ & $\mathbf{C l a s s}^{\mathbf{2}}$ & $\mathbf{E \%}^{\mathbf{1}}$ & $\mathbf{C l a s s}^{\mathbf{2}}$ \\
\hline Chlorantraniliprole 10 & 8.3 & 1 & 0 & 1 & 0 & 1 \\
Chlorantraniliprole 15 & 10.6 & 1 & 0 & 1 & 0 & 1 \\
Chlorantraniliprole 20 & 5.1 & 1 & 0 & 1 & 0 & 1 \\
Chlorantraniliprole 30 & 20.8 & 1 & 0 & 1 & 0 & 1 \\
Chlorantraniliprole 50 & 31.4 & 2 & 14.5 & 1 & 0 & 1 \\
Chlorantraniliprole 10 + lambda-cyhalothrin 5 & 14.1 & 1 & 0 & 1 & 0 & 1 \\
Chlorantraniliprole 20 + lambda-cyhalothrin 10 & 13.9 & 1 & 3.1 & 1 & 0 & 1 \\
Chlorantraniliprole 30 + lambda-cyhalothrin 15 & 21.1 & 1 & 5.9 & 1 & 0 & 1 \\
Chlorpyrifos 960 & 63.5 & 2 & 52.9 & 2 & 76.3 & 2 \\
\hline
\end{tabular}

$1 \mathrm{E}(\%)=(1-\mathrm{Vt} / \mathrm{Vc}) \times 100$; where, $\mathrm{E}(\%)$ is the percentage of reduction in parasitism or emergence of parasitoids; $2 \mathrm{Classes}: 1=$ innocuous $(\mathrm{E}<30 \%), 2=$ slightly harmful $(30 \leq \mathrm{E} \leq 79 \%), 3=$ moderately harmful $(80 \leq \mathrm{E} \leq 99 \%)$, and $4=$ noxious $(\mathrm{E}>99 \%)$.

Table 5. Total number of eggs parasitized/female, emergence (\%), sex ratio, and longevity (days) of female Telenomus podisi adults from pupae sprayed with various concentrations of chlorantraniliprole and chlorantraniliprole + lambdacyhalothrin.

\begin{tabular}{|c|c|c|c|c|}
\hline $\begin{array}{c}\text { Treatments (dose } / 150 \mathrm{~L} \\
\left.\mathrm{H}_{2} \mathrm{O}\right)\end{array}$ & $\begin{array}{c}\text { Total eggs } \\
\text { parasitized/female } \\
\end{array}$ & Emergence $^{1}$ & Sex Ratio ${ }^{1}$ & $\begin{array}{c}\text { Longevity of } \\
\text { female parents }\end{array}$ \\
\hline Chlorantraniliprole 10 & $84.85 \pm 7.63 a$ & $58.05 \pm 3.16 \mathrm{a}$ & $0.47 \pm 0.01 \mathrm{a}$ & $15.70 \pm 1.12 \mathrm{ab}$ \\
\hline Chlorantraniliprole 15 & $95.07 \pm 9.88 \mathrm{a}$ & $47.93 \pm 4.85 \mathrm{a}$ & $0.45 \pm 0.07 \mathrm{ab}$ & $15.85 \pm 1.56 \mathrm{ab}$ \\
\hline Chlorantraniliprole 20 & $79.20 \pm 10.23 \mathrm{a}$ & $55.04 \pm 3.57 \mathrm{a}$ & $0.58 \pm 0.02 \mathrm{a}$ & $15.75 \pm 1.38 \mathrm{ab}$ \\
\hline Chlorantraniliprole 30 & $102.85 \pm 3.86 a$ & $55.41 \pm 2.99 a$ & $0.61 \pm 0.04 \mathrm{a}$ & $14.85 \pm 0.80 \mathrm{ab}$ \\
\hline Chlorantraniliprole 50 & $96.30 \pm 3.94 a$ & $55.22 \pm 2.79 a$ & $0.66 \pm 0.05 \mathrm{a}$ & $15.65 \pm 1.34 \mathrm{ab}$ \\
\hline $\begin{array}{c}\text { Chlorantraniliprole } 10+ \\
\text { lambda-cyhalothrin } 5\end{array}$ & $99.95 \pm 6.85 \mathrm{a}$ & $56.15 \pm 2.39 \mathrm{a}$ & $0.49 \pm 0.09 \mathrm{a}$ & $17.85 \pm 1.09 \mathrm{ab}$ \\
\hline $\begin{array}{l}\text { Chlorantraniliprole } 20+ \\
\text { lambda-cyhalothrin } 10\end{array}$ & $93.55 \pm 4.10 \mathrm{a}$ & $53.98 \pm 2.96 \mathrm{a}$ & $0.14 \pm 0.05 b c$ & $15.55 \pm 0.49 \mathrm{ab}$ \\
\hline $\begin{array}{c}\text { Chlorantraniliprole } 30+ \\
\text { lambda-cyhalothrin } 15\end{array}$ & $92.06 \pm 9.51 \mathrm{a}$ & $58.20 \pm 1.59 a$ & $0.36 \pm 0.03 \mathrm{ab}$ & $14.20 \pm 1.56 b$ \\
\hline Water & $106.60 \pm 7.44 a$ & $54.81 \pm 3.67 \mathrm{a}$ & $0.40 \pm 0.05 \mathrm{ab}$ & $19.55 \pm 0.17 \mathrm{a}$ \\
\hline Chlorpyrifos 960 & $0.5 \pm 0.36 \mathrm{~b}$ & $8.33 \pm 8.33 b$ & $0 \mathrm{c}$ & $1.00 \pm 0.00 \mathrm{c}$ \\
\hline CV (\%) & 16.18 & 14.18 & 24.44 & 14.47 \\
\hline $\mathrm{F}$ & 20.05 & 13.20 & 8.67 & 22.42 \\
\hline$p$ & $<0.0001$ & $<0.0001$ & $<0.0001$ & $<0.0001$ \\
\hline
\end{tabular}

${ }^{1}$ Means $( \pm$ SE) followed by the same letter in the column do not differ according to the Tukey test $(p>0.05)$.

The lifetime parasitism decreased over the life of the females. For all treatments, peaks in parasitism occurred on the first and third day of egg exposure (Figures 1 and 2). The maximum amount of parasitized eggs per day was observed for the treatment containing chlorantraniliprole at $30 \mathrm{~g}$ a.i. ha $^{-1}$ (Figures 1 and 2). For the same treatment, a parasitism rate of $80 \%$ was reached between days 8 and 9. The other treatments ranged from the day 9 to 10 , as well as having a lower number of parasitized eggs per day (1.2 eggs) on the day 15. For chlorpyrifos, due to the mortality rate of $100 \%$ of the parasitoids, it was not possible to assess parasitism capacity. 
Figure 1. Parasitism of Telenomus podisi on Euschistus heros eggs when chlorantraniliprole has been applied; A) $10 \mathrm{~g}$ a.i. ha ${ }^{-1}$ chlorantraniliprole (Premio $\left.{ }^{\circledR}\right)$; B) $15 \mathrm{~g}^{\text {a.i. }} \mathrm{ha}^{-1}$ chlorantraniliprole (Premio ${ }^{\circledR}$ ); C) $20 \mathrm{~g}$ a.i. ha ${ }^{-1}$ chlorantraniliprole (Premio $\left.{ }^{\circledR}\right)$; D) $30 \mathrm{~g}$ a.i. ha ${ }^{-1}$ chlorantraniliprole (Premio $\left.{ }^{\circledR}\right)$; E) 50 g a.i. ha ${ }^{-1}$ chlorantraniliprole (Premio ${ }^{\circledR}$ ). The arrows indicate $80 \%$ of lifetime parasitism.
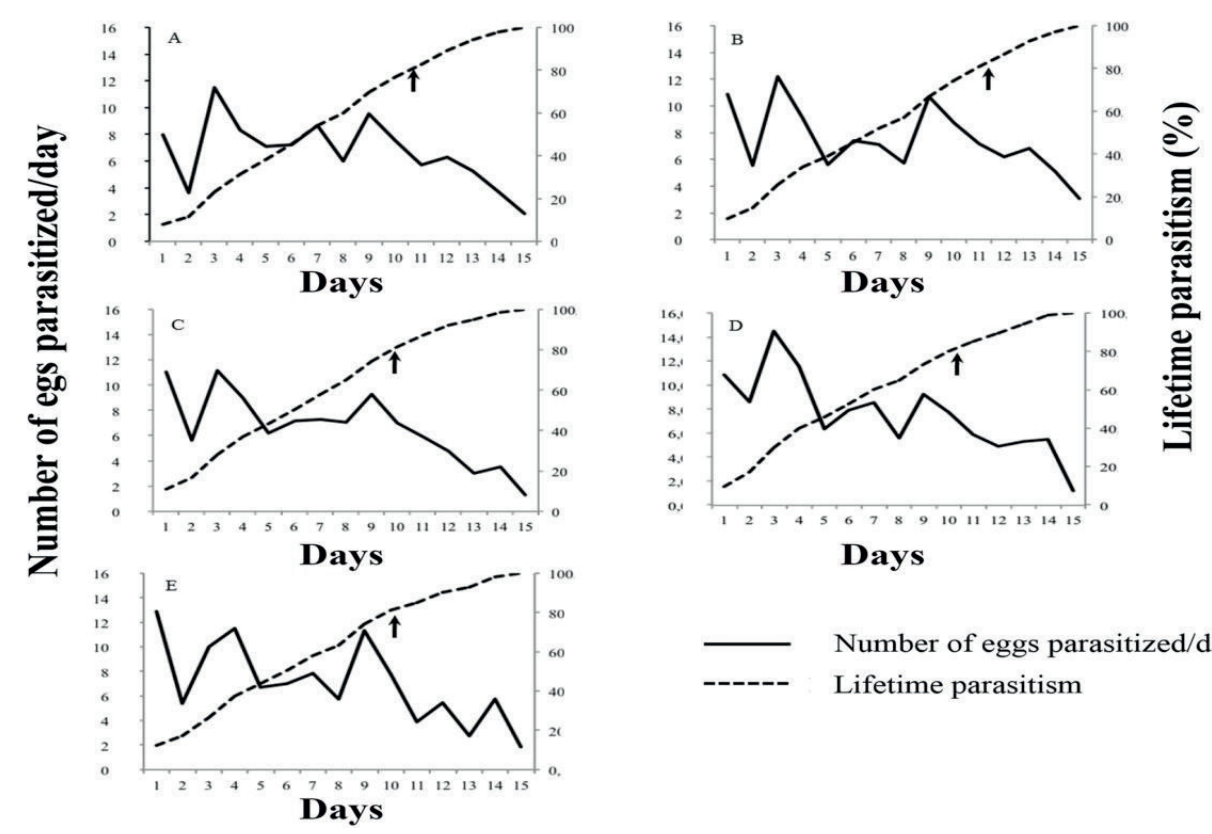

Days

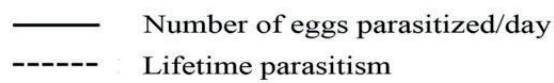

Figure 2. Parasitism of Telenomus podisi on Euschistus heros eggs where chlorantraniliprole + lambda-cyhalothrin has been applied; A) $10+5 \mathrm{~g}$ a.i. ha ${ }^{-1}$ chlorantraniliprole + lambda-cyhalothrin (Ampligo®); B) $20+10 \mathrm{~g}$ a.i. ha ${ }^{-1}$ chlorantraniliprole + lambda-cyhalothrin (Ampligo $\left.{ }^{\circledR}\right)$; C) $30+15$ g a.i. ha-1 chlorantraniliprole + lambda-cyhalothrin (Ampligo $\left.{ }^{\circledR}\right)$; D) negative control - water. The arrows indicate $80 \%$ of lifetime parasitism.

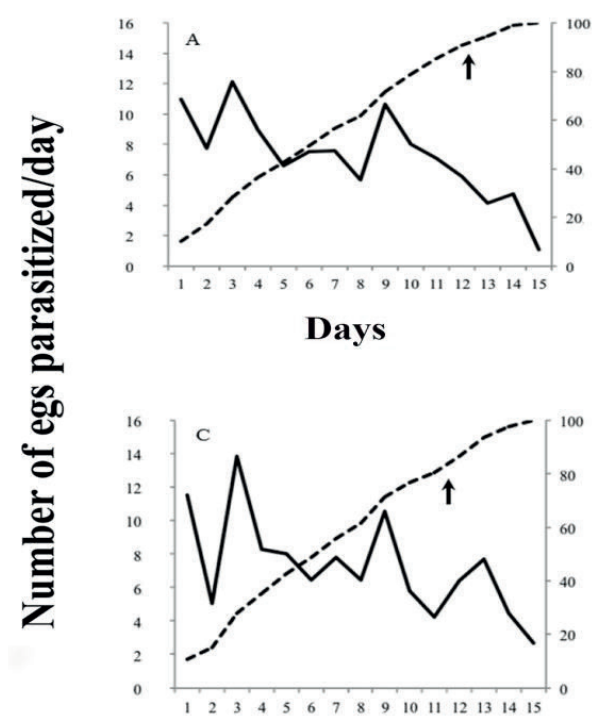

Days

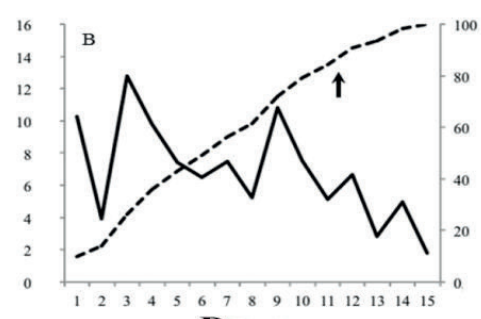

Days

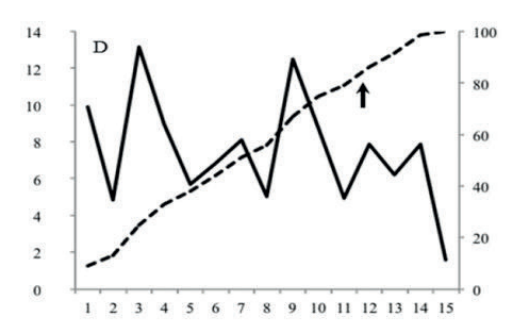

Days

Number of eggs parasitized/day

Lifetime parasitism 
Selectivity of chlorantraniliprole and mixture of chlorantraniliprole + lambda-cyhalothrin chlorantraniliprole + lambda-cyhalothrin to $T$. at $10+5 \mathrm{~g} \mathrm{a.i.} \mathrm{ha}^{-1}$ showed the lowest percentage podisi adults

The percentage of parasitism varied among treatments in all periods tested and, at 24 hours, did not exceed $47 \%$. The lowest level of parasitism occurred in the treatment with chlorpyrifos $(1.27 \%)$, followed by the mixture of chlorantraniliprole + lambda-cyhalothrin at $30+15 \mathrm{~g}$ a.i. ha ${ }^{-1}(15.12 \%)$, chlorantraniliprole + lambda-cyhalothrin at $20+$ 10 g a.i. ha ${ }^{-1}(28.45 \%)$, and chlorantraniliprole + lambda-cyhalothrin at $10+5 \mathrm{~g}$ a.i. ha ${ }^{-1}(31.15 \%)$. Treatments with chlorantraniliprole, as well as with water, had similar percentages. 72 hours after contact between $T$. podisi adults and the respective products, the percentage of parasitism was similar in the concentrations of chlorantraniliprole and water, with values between $63.30 \%$ and $82.53 \%$ for chlorantraniliprole at $30 \mathrm{~g}$ a.i. ha ${ }^{-1}$ and $10 \mathrm{~g}$ a.i. ha- ${ }^{-1}$, respectively. For the chlorantraniliprole + lambdacyhalothrin mixtures at $10+5 \mathrm{~g}$ a.i. ha ${ }^{-1}$ and $20+10$ g a.i. $\mathrm{ha}^{-1}$, parasitism was lower than for the other treatments, with percentages of $53 \%$ and $25.33 \%$, respectively. For the highest concentration of the chlorantraniliprole + lambda-cyhalothrin mixture at $30+15 \mathrm{~g}$ a.i. ha- $\mathrm{h}^{-1}$ and the positive control of chlorpyrifos, after 72 hours, there was no parasitism (Table 6). In the last assessment, 120 hours after adult contact with pesticides, parasitism did not differ between chlorantraniliprole and water, with values between $67.04 \%$ (30 $\mathrm{g}$ a.i. ha $\mathrm{h}^{-1}$ chlorantraniliprole) and $83.54 \%$ (10 g a.i. ha ${ }^{-1}$ chlorantraniliprole). The of parasitism $(11.33 \%)$. For the mixtures with the highest doses, as well as the positive control with chlorpyrifos, there was no parasitism observed due to death of the parasitoids (Table 6).

Data on emergence differed only at 24 hours, when the lowest value observed was that of the treatment with chlorpyrifos $(25 \%)$ and the highest values were for the mixture of chlorantraniliprole + lambda-cyhalothrin at $30+15 \mathrm{~g}$ a.i. ha ${ }^{-1}$ (64.63\%), chlorantraniliprole at $20 \mathrm{~g}$ a.i. ha ${ }^{-1}(61 \%)$, chlorantraniliprole at $10 \mathrm{~g}$ a.i. $\mathrm{ha}^{-1}(60 \%)$, and chlorantraniliprole + lambda-cyhalothrin at $10+$ $5 \mathrm{~g}$ a.i. $\mathrm{ha}^{-1}(58.17 \%)$. In the other treatments, the percentages of emergence were intermediate (Table 6).

Regarding the classification of toxicity of insecticides according to IOBC parameters, all the concentrations of chlorantraniliprole tested were not toxic to parasitoids at 24, 72, and 120 hours after contact with adult insects. The mixture of chlorantraniliprole + lambda-cyhalothrin $10 \mathrm{~g}$ a.i. $+5 \mathrm{ha}^{-1}$ was not toxic to the parasitoid 24 and 72 hours after contact with adult insects. These concentrations were classified as harmless (class 1) (Table 7). The mixture of chlorantraniliprole + lambda-cyhalothrin at $10+5 \mathrm{~g}$ a.i. ha ${ }^{-1}, 120$ hours after contact with the parasitoids, caused an $86.31 \%$ reduction in parasitism of adults and was thus classified as moderately harmful (Table 7). 


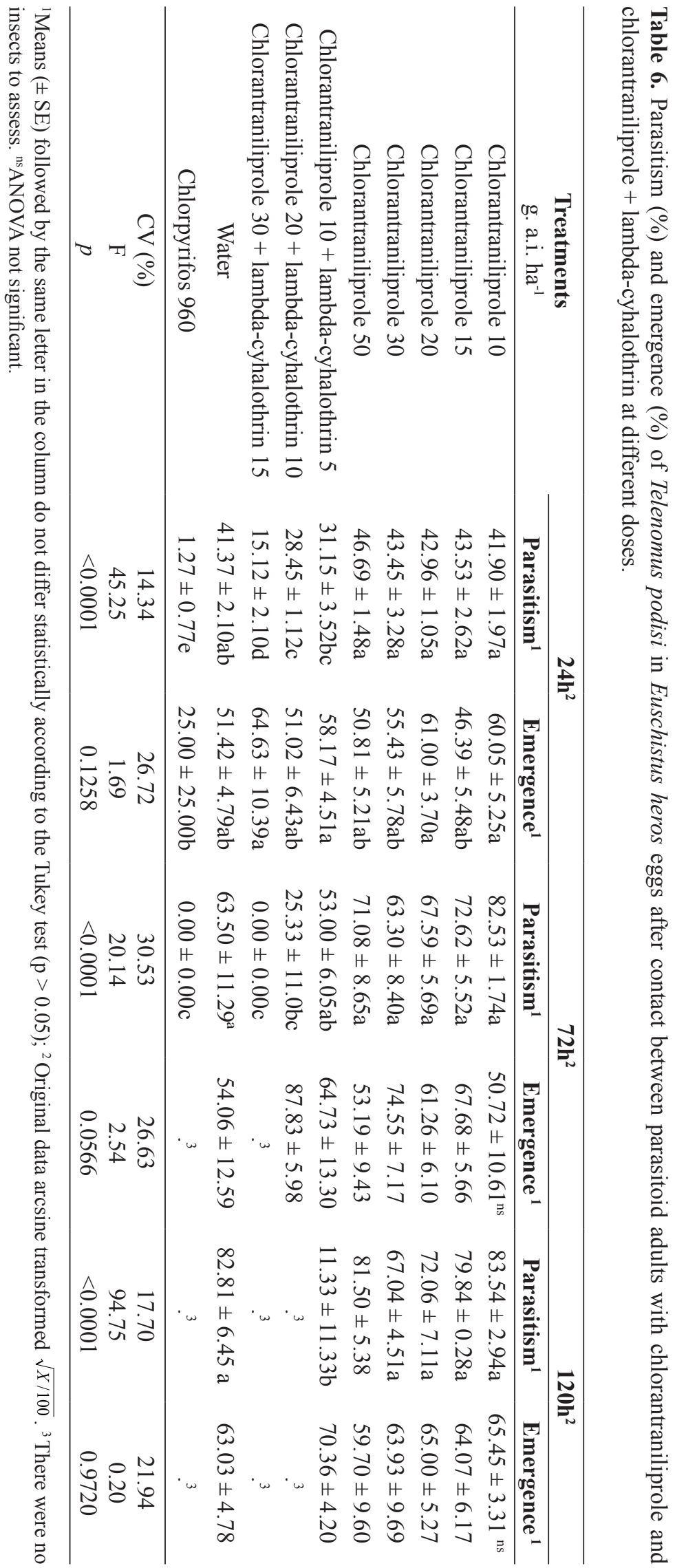


Table 7. Effect of different insecticides and doses on adults of Telenomus podisi and their classification according to the norms of the International Organization for Biological Control (IOBC).

\begin{tabular}{|c|c|c|c|c|c|c|}
\hline \multirow{2}{*}{$\begin{array}{l}\text { Treatments } \\
\text { g. a.i. ha }\end{array}$} & \multicolumn{2}{|c|}{$24 \mathrm{~h}$} & \multicolumn{2}{|c|}{$72 \mathrm{~h}$} & \multicolumn{2}{|c|}{$120 \mathrm{~h}$} \\
\hline & $\mathbf{E} \%{ }^{1}$ & Class $^{2}$ & $\mathbf{E \%}{ }^{1}$ & Class $^{2}$ & $\mathbf{E \%}{ }^{1}$ & Class $^{2}$ \\
\hline Chlorantraniliprole 10 & 0 & 1 & 0 & 1 & 0 & 1 \\
\hline Chlorantraniliprole 15 & 0 & 1 & 0 & 1 & 3.6 & 1 \\
\hline Chlorantraniliprole 20 & 0 & 1 & 0 & 1 & 12.9 & 1 \\
\hline Chlorantraniliprole 30 & 0 & 1 & 0.4 & 1 & 19.0 & 1 \\
\hline Chlorantraniliprole 50 & 0 & 1 & 0 & 1 & 1.6 & 1 \\
\hline Chlorantraniliprole $10+$ lambda-cyhalothrin 5 & 24.7 & 1 & 19.6 & 1 & 86.3 & 3 \\
\hline Chlorantraniliprole $20+$ lambda-cyhalothrin 10 & 31.2 & 2 & 60.1 & 2 & 100 & 4 \\
\hline Chlorantraniliprole 30 + lambda-cyhalothrin 15 & 63.4 & 2 & 100 & 4 & 100 & 4 \\
\hline Chlorpyrifos 960 & 96.9 & 3 & 100 & 4 & 100 & 4 \\
\hline
\end{tabular}

${ }^{1} \mathrm{E}(\%)=(1-\mathrm{Vt} / \mathrm{Vc}) \times 100$; where, $\mathrm{E}(\%)$ is the percentage of reduction in parasitism or emergence of parasitoids; ${ }^{2} \mathrm{Classes:} 1=$ innocuous $(\mathrm{E}<30 \%), 2=$ slightly harmful $(30 \leq \mathrm{E} \leq 79 \%), 3=$ moderately harmful $(80 \leq \mathrm{E} \leq 99 \%)$, and $4=$ noxious $(\mathrm{E}>99 \%)$.

The highest concentrations of the mixtures chlorantraniliprole + lambda-cyhalothrin at $20+10$ g a.i. ha ${ }^{-1}$ and $30+15$ g a.i. ha ${ }^{-1}-$ reduced parasitism after 24 hours to $31.23 \%$ and $63.44 \%$, respectively. These concentrations were classified as somewhat noxious (Table 7). At 72 hours after contact with the parasitoids, the same mixtures reduced parasitism to $60.13 \%$ and $100 \%$, respectively, and were considered slightly noxious at $20+10 \mathrm{~g}$ a.i. ha ${ }^{-1}$ and noxious at $30+15 \mathrm{~g}$ a.i. ha ${ }^{-1}$. After 120 hours, both reduced the parasitism of $T$. podisi by $100 \%$ and were classified as noxious (Table 7).

Spraying with chlorpyrifos was classified as moderately harmful 24 hours after contact with parasitoids, with a $96.92 \%$ reduction in parasitism (Table 7). For the other periods tested, 72 hours and 120 hours after contact, the reduction in parasitism was $100 \%$, resulting in a classification of noxious to T. podisi adults (Table 7).

\section{Discussion}

Even with the reported toxicity of chlorantraniliprole in different doses to non-target organisms belonging to various groups, such as Daphnia magna (Crustacea) (LAVTIZAR et al., 2015) and to nymphs of Amphiareus constrictus
(Stal) and Blaptostethus pallescens (Poppius) (Heteroptera: Anthocoridae) (GONTIJO et al., 2015), in general, this study found no significant influence of this product on the development of $T$. podisi. Accordingly, the product shows characteristics that allow us to consider it to be selective (LAHM et al., 2009; SPARKS et al., 2015). In addition, this molecule acts mainly on insects of the order Lepidoptera (IRAC, 2016), which may be related to its low degree of interference in the $T$. podisi parasitoid.

Thus, chlorantraniliprole has been classified as harmless to adult insects and pupae, except at the highest dose tested (50 g a.i. ha ${ }^{-1}$ ). Similar results were observed for other species of egg parasitoids of the Trichogrammatidae family (PREETHA et al., 2009; BRUGGER et al., 2010; UMA et al., 2014) and for T. podisi in rice (PAZINI et al., 2016), where chlorantraniliprole was classified as innocuous at $31.5 \mathrm{~g}$ a.i. ha ${ }^{-1}$. However, the highest dose of chlorantraniliprole still needs to be assessed in the field, where variables such as rain, wind, sunlight, and others minimize the action of the product on the organism. Additional studies are needed to address these factors.

In tests with Trichogramma galloi (Zucchi) (Hymenoptera: Trichogrammatidae), 
chlorantraniliprole led to a reduction in mortality of less than $30 \%$ and was classified as innocuous at $350 \mathrm{~g}$ a.i. ha- ${ }^{-1}$ (OLIVEIRA et al., 2013). For Trichogramma pretiosum pupae (Riley) (Hymenoptera: Trichogrammatidae), chlorantraniliprole was considered slightly harmful (BARROS, 2016), which in the present study occurred only with the highest dose of the product, in the first 24 hours of assessment for T. podisi. For adult insects, at all concentrations and periods tested, chlorantraniliprole was shown to be innocuous. Generally, the adult phase of the parasitoid is more sensitive to pesticides, compared to the pupal phase, which is considered more tolerant (CARMO et al., 2009). This is because the pupa is protected within the egg of the host during the pupal phase. The chorion of the host egg provides protection to the developing parasitoid, preventing the pesticide from reaching the parasitoid pupa inside the host (BUENO et al., 2017). However, the higher toxicity of chlorantraniliprole on pupae observed in this work can be explained by the penetration of the product through the chorion of host eggs due to their lipophilicity, thus leading to lack of viability of adult emergence (MACBEAN, 2012).

According to Brugger et al. (2010), there is no significant reduction in the emergence of $T$. pretiosum after application of chlorantraniliprole to $H$. armigera eggs. According to those authors, this insecticide can be viably used in IPM programs due to its selectivity with regard to non-target organisms, especially parasitoids. This result was also found in the present study. Thus, chlorantraniliprolebased products may allow for the concurrent use of biological and chemical control, with regard to the use of $T$. podisi.

In this study, the mixture of chlorantraniliprole + lambda-cyhalothrin significantly reduced the parasitism of T. podisi. Its negative effect intensified during the assessments, classified at 120 hours as harmful at the highest concentrations tested.
According to Paiva (2016), the effect of the mixture of pyrethroid and neonicotinoid was also harmful to the $T$. pretiosum parasitoid. With the present results, decreased parasitism was also observed under the effect of chlorantraniliprole + lambdacyhalothrin, demonstrating negative interference in the performance of the insect. This fact can be explained by the different modes of action of the insecticides, which together intensified their effect on parasitoid activity.

Regarding the parasitic capacity of the $F_{1}$ generation of T. podisi, neither chlorantraniliprole nor the mixture of chlorantraniliprole + lambdacyhalothrin affected the total number of eggs that were parasitized, the viability of parasitism, or the sex ratio. This demonstrates that the spraying of various products and doses does not affect performance of the second generation of the parasitoid (sublethal effects).

In general, the adult phase of $T$. podisi was more sensitive to the products and doses applied. This pattern was also observed for other species of parasitoids (BUENO et al., 2008). Thus, the present study provides information for making choices about the insecticide to be used in pest management, favoring the integration of chemical and biological control, with the aim of better preserving natural enemies in agroecosystems.

\section{Conclusion}

Chlorantraniliprole was selective to T. podisi at the doses studied and can be considered a tool in IPM for soybeans, since it demonstrates low or null negative interference in the development of the parasitoid when sprayed on pupae and adults. However, the mixture of chlorantraniliprole + lambda-cyhalothrin should be used with caution in IPM, as it interferes negatively in the development of the parasitoid and should be substituted with a more selective product whenever possible. 


\section{Acknowledgements}

The authors are grateful to Embrapa Soybean, the National Council for Scientific and Technological Development (CNPq) (processes 303779/20152 and 402797/2016-7) and the Coordination for the Improvement of Higher Education Personnel (CAPES) for granting financial aid and scholarships.

\section{References}

BARROS, L. S. Seletividade de inseticidas ao parasitoide de ovos Trichogramma Pretiosum (Hymenoptera: Trichogrammatidae). 2016. Dissertação (Mestrado em Agronomia: Proteção de Plantas) - Universidade Estadual Paulista Júlio de Mesquita Filho, Botucatu.

BRUGGER, K. E.; COLE, P. G.; NEWMAN, I. C.; PARKER, N.; SCHOLZ, B.; SUVAGIA, P.; WALKERF, G.; HAMMONDG, T. G. Selectivity of chlorantraniliprole to parasitoid wasps. Pest Management Science, Sussex, v. 66, n. 10 , p. 1075-1081, 2010.

BUENO, A. F.; BUENO, R. C. O. F.; PARRA, J. R. P.; VIEIRA, S. S. Effects of pesticides used in soybean crops to the egg parasitoid Trichogramma pretiosum. Ciência Rural, Santa Maria, v. 38, n. 6, p. 1495-1503, 2008.

BUENO, A. F.; CARVAlHO, G. A.; SANTOS, A. C.; SOSA-GÓMEZ, D. R.; SILVA, D. M. Pesticide selectivity to natural enemies: challenges and constraints for research and field recommendation. Ciência Rural, Santa Maria, v. 47, n. 6, p. 1-10, 2017.

BUENO, A. F.; SOSA-GÓMEZ, D. R.; CORRÊAFERREIRA, B. S.; MOSCARDI, F.; BUENO, R. C. O F. Inimigos naturais das pragas da soja. In: HOFFMANNCAMPO, C. B.; CORRÊA-FERREIRA, B. S.; MOSCARDI, F. (Ed.). Soja: manejo integrado de insetos e outros Artrópodes-praga. Brasília, DF: Embrapa, 2012. p. 493-630.

BURR, I. W.; FOSTER, L. A. A test for equality of variances. West Lafayette: University of Purdue, 1972. $26 \mathrm{p}$.

CARMO, E. L.; BUENO, A. F.; BUENO, R. C. O. F.; VIEIRA, S. V.; GOBBI, A. L.; VASCO, F. R. Seletividade de diferentes agrotóxicos usados na cultura da soja ao parasitoide de ovos Telenomus remus. Ciência Rural, Santa Maria, v. 39, n. 8, p. 2293-2300, 2009.

CORRÊA-FERREIRA, B. S.; AZEVEDO, J. Soybean seed damage by different species of stink bugs. Agricultural and Forest Entomology, Rockville Pike, v. 4, n. 2, p. 145-150, 2002.
CZEPAK, C.; ALBERNAZ, K. C.; VIVAN, L. M.; GUIMARÃES, H. O.; CARVALHAIS, T. Primeiro registro da ocorrência de Helicoverpa armigera (Hubner) (Lepidoptera: Noctuidae) no Brasil. Pesquisa Agropecuária Tropical, Goiânia, v. 43, n. 1, p. 110-113, 2013.

DEGRANDE, P. E.; REIS, P. R.; CARVALHO, G. A.; BELARMINO, L. C. Metodologia para avaliar o impacto de pesticidas sobre inimigos naturais. In: PARRA, J. R. P.; BOTELHO, P. S. M.; CORRÊA-FERREIRA, B. S.; BENTO, J. M. S. (Ed.). Controle biológico no Brasil: parasitóides e predadores. São Paulo: Manole, 2002. p. 71-93.

DESNEUX, N.; RAFALIMANANA, H.; KAISER, L. Dose-response relationship in lethal and behavioural effects of different insecticides on the parasitic wasp Aphidius ervi. Chemosphere, Amsterdam, v. 54, n. 5, p. 619-627, 2004.

DIAMANTINO, E. P.; CASTELLANI, M. A.; FORTI, L. C.; MOREIRA, A. A.; JOSÉ, A. R. S.; MACEDO, J. A.; OLIVEIRA, F. S.; SILVA, B. S. Seletividade de inseticidas a alguns dos inimigos naturais na cultura do algodão. Arquivos do Instituto Biológico, Campinas, v. 81, n. 2, p. 150-158, 2014.

DOETZER, A. K.; FOERSTER, L. A. Desenvolvimento, Longevidade e Reprodução de Trissolcus basalis (Wollaston) e Telenomus podisi Ashmead (Hymenoptera: Scelionidae) em Condições Naturais durante a Entressafra da Soja no Sul do Paraná. Neotropical Entomology, Londrina, v. 2, n. 36, p. 233-242, 2007.

FONSECA, P. R. B.; MOTA, T. A.; KASSAB, S. O.; FERNANDES, M. G. Seletividade de inseticidas utilizados no controle da Spodoptera frugiperda (J.E. Smith, 1797) nos inimigos naturais epigéicos na cultura do milheto. Revista Caatinga, Mossoró, v. 25, n. 1, p. 14-19, 2012.

GONTIJO, L. M.; CELESTINO, D.; QUEIROZ, O. S.; GUEDES, R. N. C.; PICANÇO, M. C. Impacts of azadirachtin and chlorantraniliprole on the developmental stages of pirate bug predators (Hemiptera: Anthocoridae) of the tomato pinworm Tuta absoluta (Lepidoptera: Gelechiidae). Florida Entomologist, Gainesville, v. 98, n. 1, p. 59-64, 2015.

HASSAN, S. A.; BIGLER, F.; BLAISINGER, P.; BOGENSCHÜTZ, H.; BRUN, J.; CHIVERTON, P.; DICKLER, E.; EASTERBROOK, M. A.; EDWARDS, P. J.; ENGLERT, W. D.; FIRTH, S. I.; HUANG, P.; INGLESFIELD, C.; KLINGAUF, F.; KÜHNER, C.; LEDIEU, M. S.; NATON, E.; OOMEN, P. A.; OVERMEER, W. P. J.; PLEVOETS, P.; REBOULET, J. N.; RIECKMANN, W.; SAMSOSE-PETERSEN, 
L.; SHIRES, S. W.; STÄUBLI, A.; STEVENSON, J.; TUSET, J. J.; VANWETSWINKEL, G.; VAN ZO, A. Q. Standard method to test the side-effects of pesticides on natural enemies of insects and mites developed by the IOBC/WPRS Working Group "Pesticides and Beneficial Organisms". EPPO Bulletin, Medford, v.15, n. 2, p. 214$255,1985$.

HASSAN, S. A.; HAFES, B.; DEGRANDE, P. E.; HERAI, K. The side-effects of pesticides on the egg parasitoid Trichogramma cacoeciae Marchal (Hym., Trichogrammatidae), acute dose-response and persistence tests. Journal of Applied Entomology, Berlin, v. 122, n. 1-5, p. 569-573, 1998.

IRAC. Comitê de Ação à Resistência de Inseticidas. Classificação modo de ação de inseticidas. Mogi Mirim, 2016. Disponível em: <http://media.wix.com/ugd/2bed 6c_91333a97a3db478cbbe1d363af09cf84.pdf>. Acesso em: 05 out. 2016.

LAHM, G. P.; CORDOVA, D.; BARRY, J. D. New and selective ryanodine receptor activators for insect control. Bioorganic and Medicinal Chemistry, Oxford, v. 17, n. 12, p. 4127-4133, 2009.

LAVTIZAR, V.; HELMUS, R.; KOOLS, S. A.; DOLENC, D.; VAN GESTEL, C. A.; TREBŠE, P.; WAAIJERS, S. L.; KRAAK, M. H. Daphnid life cycle responses to the insecticide Chlorantraniliprole and its transformation products. Environmental Science and Technology, Washington, v. 6, n. 49, p. 3922-3929, 2015.

MACBEAN, C. The pesticide manual. $16^{\text {th }}$ ed. British Crop Production Council: Alton, Hampshire, UK, 2012.

OLIVEIRA, H. N.; ANTIGO, M. R.; CARVALHO, G. A.; GLAESER, D. F.; PEREIRA, F. F. Seletividade de inseticidas utilizados na cana-de-açúcar a adultos de Trichogramma galloi Zucchi (Hymenoptera: Trichogrammatidae). Bioscience Journal, Uberlândia, v. 29, n. 5, p. 1267-1274, 2013.

PAIVA, A. C. R. Toxicidade e efeito subletal dos principais inseticidas utilizados na cultura da soja para Trichogramma pretiosum (Hymenoptera: Platygastridae). 2016. Dissertação (Mestrado em Entomologia) - Escola Superior de Agricultura Luiz de Queiroz, Piracicaba.

PAZINI, J. B.; GRÜTZMACHER, A. D.; MARTINS, J. F. S.; PASINI, R. A.; RAKES, M. Selectivity of pesticides used in rice crop on Telenomus podisi and Trichogramma pretiosum. Pesquisa Agropecuária Tropical, Goiânia, v. 46, n. 3, p. 327-335, 2016.

POLANCZYK, R. A.; PRATISSOLI, D.; DALVI, L. P.; GRECCO, E. D.; FRANCO, C. R. Efeito de Beauveria bassiana (Bals) e Metarhizium anisopliae nos parâmetros biológicos de Trichogrammma atopovirilia (Hymenoptera: Trichogrammatidae). Ciência $e$ Agrotecnologia, Lavras, v. 34, n. 6, p. 1412-1416, 2010.

POMARI-FERNANDES, A.; BUENO, A. de F.; SOSAGÓMEZ, D. R. Helicoverpa armigera: current status and future perspectives in Brazil. Current Agricultural Science and Technology, Pelotas, v. 21, n. 1, p. 1-7, 2015.

PREETHA, G.; STANLEY, J.; KUTTALAM, S.; RAMASAMY, S. Toxicity of selected insecticides to Trichogramma chilonis: assessing their safety in the rice ecosystem. Phytoparasitica, Rehovot, v. 37, n. 3, p. 209215, 2009.

REIS, P. R.; CHIAVEGATO, L. G.; MORAES, G. J.; ALVES, E. B.; SOUSA, E. O. Seletividade de agroquímicos ao ácaro predador Iphiseiodes zuluagai Denmark \& Muma (Acari: Phytoseiidae). Anais de Sociedade Entomológica do Brasil, Londrina, v. 27, n. 2, p. 265-274, 1998.

SAS Institute. SAS/STAT: User's guide. Version 9.2. Cary, NC: SAS, 2009.

SHAPIRO, S. S.; WILK, M. B. An analysis of variance test for normality (complete sample). Biometrika, Oxford, v. 52, n. 3-4, p. 591-611, 1965.

SPARKS, T. C.; NAUEN, R. IRAC: mode of action classification and insecticide resistance management. Pesticide Biochemistry and Physiology, San Diego, v. 121, p. 122-128, 2015.

UMA, S.; JACOB, S.; LYLA, K. R. Acute contact toxicity of selected conventional and novel insecticides to Trichogramma japonicum Ashmead (Hymenoptera: Trichogrammatidae). Journal of Biopesticides, Palayamkottai, v. 7, n. 1, p. 133-136, 2014.

WANG, N. C.; LI, Z. H. Studies on the biology of cotton bollworm (Heliothis armigera Hübner) and tobacco budworm (Heliothis assulta Quenee). Journal of the Shandong Agricultural University, Taian, v. 1-2, n. 1, p. 13-25, 1984.

WYCKHUYS, K. A.; LU, Y.; MORALES, H.; VAZQUEZ, L. L.; LEGASPI, J. C.; ELIOPOULOS, P. A.; HERNANDEZ, L. M. Current status and potential of conservation biological control for agriculture in the developing world. Biological Control, San Diego, v. 65, n. 1, p.152-167. 2013.

ZOTTI, M. J.; GRÜTZMACHER, A. D.; GRÜTZMACHER, D. D.; DALMAZZO, G. O.; MARTINS, J. F. S. Seletividade de inseticidas usados na cultura do milho para ninfas e adultos do predador Doru lineare (Eschscholtz, 1822) (Dermaptera: Forficulidae) em condições de semi-campo. Revista Brasileira de Agrociência, Pelotas, v. 14, n. 3, p. 96-105, 2008. 
